\title{
USEFULNESS OF THE FULLERTON TEST IN QUALIFYING PATIENTS WITH CHRONIC OBSTRUCTIVE PULMONARY DISEASE FOR REHABILITATION
}

\author{
Jan Szczegielniak ${ }^{1,2}$, Anna Wdowiak ${ }^{1}$, Katarzyna Bogacz ${ }^{1,2}$, Jacek Luniewski ${ }^{1}$ \\ Opole University of Technology \\ MSWiA Hospital in Glucholazy ${ }^{2}$
}

\section{SUMMARY}

Adequate, individually based choice of training type and intensity is a prerequisite for physiotherapy of patients with COPD. The basic criteria for qualification include effort tolerance assessment by means of exercise test on cycloergometer or treadmill or 6-minute walk test and determining the degree of lung ventilation activity impairment, dyspnea level and patient's physical condition. The Fullerton test is an easy and time-effective tool allowing for effort tolerance and physical condition assessment in case of patients above the age of 60 . The objective of this work was to assess the usefulness of the Fullerton test in qualifying patients with COPD for rehabilitation.

Thirty two patients with diagnosed COPD were tested in the research. The group comprised in-patients treated in the MSWiA Hospital in Glucholazy between February 1 and May 10, 2011. All patients in the research were above 60 years of age, with median age of $68 \pm 5.2$. The patients were given pulmonary rehabilitation model A and B according to Szczegielniak. In the research, the results recorded in 6 trials of the Fullerton test were compared to the results of standard tests qualifying for pulmonary rehabilitation. For this purpose, a 10-point scale was created by the authors, which included parameters achieved in the Fullerton test allowing comparison of the results achieved in the Fullerton test and standard qualification procedure. The T-student test was used to assess the relationships between the tested parameters. Statistical significance level was established at $p<0.05$.

The analysis of research results showed that patients who scored higher on the scale were qualified for higher pulmonary rehabilitation models, which means they achieved higher results in qualification tests.

The Fullerton test might be useful for the assessment of the results and progress of pulmonary rehabilitation process.

Keywords: Fullerton test, effort tolerance assessment, pulmonary rehabilitation.

\section{INTRODUCTION}

Adequate, individually based choice of training type and intensity is a prerequisite for physiotherapy of patients with COPD. The basic criteria for qualification include effort tolerance assessment by means of exercise test on cycloergometer or treadmill or 6-minute walk test and determining the degree of lung ventilation activity impairment, dyspnea level and patient's physical condition. Achieving positive results of physiotherapy is possible with appropriately designed rehabilitation program adjusted to patient's individual needs and abilities [1, 2].

Basic crietria for qualifying for rehabilitation include effort tolerance and physical condition assessment, evaluating the level of dyspnea and functional test of respiratory system $[1,3]$.

Among effort tolerance assessment tests, exercise test on the cycloergometer or treadmill is the most frequently used one. It is conducted according to standard test protocols evaluating energy expenditure in MET or Wat and HR effort limits. The 6-minute walk test [4] and the 12-minute walk test are also frequently used [1].
Functional Fitness Test, known as the Fullerton test, was introduced in 1997 by two physiotherapists, Robert Rikli and Jessie Jones, of The Fullerton University in California. It allows for easy and repeatable functional assessment in patients above 60 years of age. The test comprises six trials which aim at indirect assessment of the upper and lower body strength, flexibility, agility, dynamic balance and aerobic endurance.

What is interesting is the fact that there is a range of simple tests enabling functional assessment in patients with COPD for rehabilitation model qualification purposes and the Functional Fitness Test seems to be one of them.

Objective. The objective of this work was to evaluate the usefulness of the Fullerton test in the process of qualifying patients with COPD for rehabilitation. The results of the six trials of the Fullerton test were compared with the results of pulmonary rehabilitation qualification tests. For this purpose, a 10-point scale determining indexes achieved in the Fullerton test was created to allow for comparison of the results of the Fullerton test and the results of standard qualification.

\section{MATERIAL AND METHODS}

Thirty two patients with diagnosed COPD were tested in the research. The median age of the patients was $68 \pm 5.2$. The group included in-patients treated in the MSWiA hospital in Glucholazy between February 1 and May 10, 2011.
All patients in the research were above 60 years of age. The patients were given pulmonary rehabilitation model A (17 patients) or B (15 patients) based on the results of the 6-minute walk test, lung ventilation activity test, 10-point Borg scale dyspnea assessment and physical condition evaluation. 
Table 1. Qualification for pulmonary rehabilitation according to J. Szczegielniak [1, 2]

\begin{tabular}{|c|c|c|c|c|}
\hline Exercise test & $\begin{array}{c}<3 \mathrm{MET} \\
<50 \mathrm{~W}\end{array}$ & $\begin{array}{c}3-4.9 \mathrm{MET} \\
50-75 \mathrm{~W}\end{array}$ & $\begin{array}{c}5-6.9 \mathrm{MET} \\
75-100 \mathrm{~W}\end{array}$ & $\begin{array}{c}\geq 7 \mathrm{MET} \\
\geq 100 \mathrm{~W}\end{array}$ \\
\hline Spirometry & $\mathrm{D}$ & $\mathrm{D}$ & $\mathrm{C}$ & $\mathrm{B} / \mathrm{A}$ \\
\hline $30-50 \%$ FEV1 & $\mathrm{D}$ & $\mathrm{D} / \mathrm{C}$ & $\mathrm{C} / \mathrm{B}$ & $\mathrm{A}$ \\
\hline $50-80 \%$ FEV1 & $\mathrm{D}$ & $\mathrm{C}$ & $\mathrm{B}$ & $\mathrm{A}$ \\
\hline$>80 \%$ FEV1 & $\mathrm{D}$ & $\mathrm{C}$ & $\mathrm{B}$ & $\mathrm{A}$ \\
\hline
\end{tabular}

All patients were given the Functional Fitness Test one day after the test qualifying for adequate rehabilitation model (Table 1).

The Fullerton test comprises the following trials:

1. Arm curl - indirectly assessing upper body strength

2. Chair stand - lower body strength assessment

3. Back scratch - upper body flexibility assessment

4. Chair sit and reach - lower body flexibility assessment

5. Foot-up and go - the agility/dynamic balance assessment

6. 6-minute walk test - indirectly assessing the level of aerobic endurance

2-minute walk-in-place can be performed instead of the 6-minute walk trial in case of patients who use orthopaedic devices during walking or in case of patients with difficulties associated with balance maintenance.
Aiming at evaluating the usefulness of the Fullerton test for pulmonary rehabilitation qualification, average values of the results and standard deviations achieved in 6 trials were calculated for each patient.

Aiming at verifying whether average values recorded for patients in rehabilitation models $A$ and $B$ differed significantly, they were compared with the T-student paired difference test at the statistical significance level of $p<0.05$.

The results recorded for all Fullerton test trials for models $A$ and $B$ formed the basis for calculating, with the use of MatLab program, a 10-point scale allowing for comparison of the Fullerton test results and standard qualification results. Each trial was awarded 1-10 points. The maximum number of points to be achieved was 60 (Table 2).

Table 2. 10-point scale for all Fullerton test trials

\begin{tabular}{|c|c|c|c|c|c|c|}
\hline $\begin{array}{c}\text { Trial } \\
\begin{array}{c}\text { Number of } \\
\text { points }\end{array}\end{array}$ & $\begin{array}{l}\text { Arm curl, } \\
\text { number of } \\
\text { repetitions }\end{array}$ & $\begin{array}{c}\text { Chair stand, } \\
\text { number of } \\
\text { repetitions }\end{array}$ & $\begin{array}{c}\text { Chair sit and } \\
\text { reach, } \\
\mathrm{cm}\end{array}$ & $\begin{array}{c}\text { Back scratch, } \\
\mathrm{cm}\end{array}$ & $\begin{array}{l}\text { 6MWT, } \\
\text { MET }\end{array}$ & $\begin{array}{l}\text { Foot-up and go, } \\
\text { s }\end{array}$ \\
\hline 1 & 13 & 10 & $(-21)-(-19)$ & $(-30)-(-28)$ & $6.6-6.3$ & $9.1-8.8$ \\
\hline 2 & 14 & 11 & $(-18)-(-16)$ & $(-27)-(-24)$ & $6.7-7.1$ & $8.7-8.4$ \\
\hline 3 & 15 & 12 & $(-15)-(-13)$ & $(-23)-(-21)$ & $7.2-7.5$ & $8.3-7.9$ \\
\hline 4 & 16 & 13 & $(-12)-(-10)$ & $(-20)-(-18)$ & $7.6-7.9$ & $7.8-7.5$ \\
\hline 5 & 17 & 14 & $(-9)-(-7)$ & $(-17)-(-14)$ & $8-8.4$ & $7.4-7.1$ \\
\hline 6 & 18 & $15-16$ & $(-6)-(-4)$ & $(-13)-(-11)$ & $8.5-8.8$ & $7.0-6.7$ \\
\hline 7 & 19 & 17 & $(-3)-(-1)$ & $(-10)-(-7)$ & $8.9-9.2$ & $6.6-6.2$ \\
\hline 8 & 20 & 18 & $0-2$ & $(-6)-(4)$ & $9.3-9.7$ & $6.1-5.8$ \\
\hline 9 & 21 & 19 & $3-5$ & $(-3)-(-1)$ & $9.8-10.1$ & $5.7-5.4$ \\
\hline 10 & 22 & 20 & 6 & 0 & 10.2 & 5.3 \\
\hline
\end{tabular}


The result analysis showed statistically significant differences between values of indexes achieved by patients in models $A$ and $B$ in the 6-minute walk test, chair stand trial and chair sit and reach trial. In the other three trials, statistically significant differences were not observed because they pertained to physical fitness and not to effort tolerance which is lower in patients with COPD (Table 3).
Statistically significant differences were recorded in the 6-minute walk test. The average result expressed in MET's [4] achieved by patients in rehabilitation model A was 8.7 MET \pm 0.8 , whereas in model $B$ it was $6.7 \pm 0.8$ (Figure 1).

The research showed statistically significant differences in the indexes of chair stand trial. Average

Table 3. Average values of analysed indexes

\begin{tabular}{|c|c|c|c|c|c|c|}
\hline $\begin{array}{c}\text { Rehabilitation } \\
\text { models }\end{array}$ & 6MWT & Chair stand & Arm curl & Back scratch & Chair sit and reach & Foot-up and go \\
\hline Model A & $8.7 \pm 0.81$ & $16.41 \pm 2.45$ & $18.88 \pm 2.23$ & $-8.94 \pm 8.17$ & $0.52 \pm 2.91$ & $6 \pm 0.61$ \\
\hline Model B & $6.71 \pm 0.8$ & $13.73 \pm 2.64$ & $16.66 \pm 3.08$ & $-16.53 \pm 6.73$ & $-6.26 \pm 7.17$ & $6.58 \pm 0.94$ \\
\hline
\end{tabular}

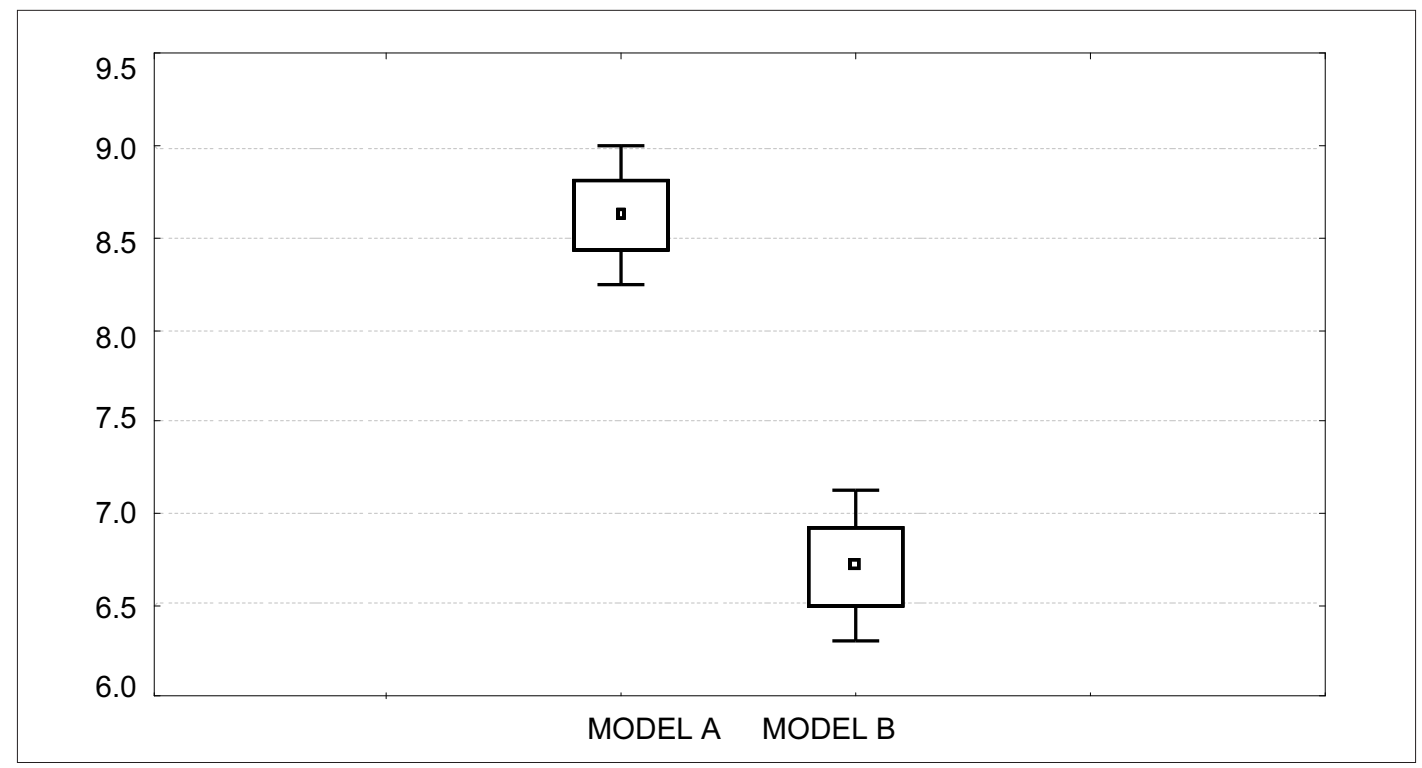

Figure 1. Average values achieved in the 6-minute walk test in rehabilitation models A and B expressed in MET

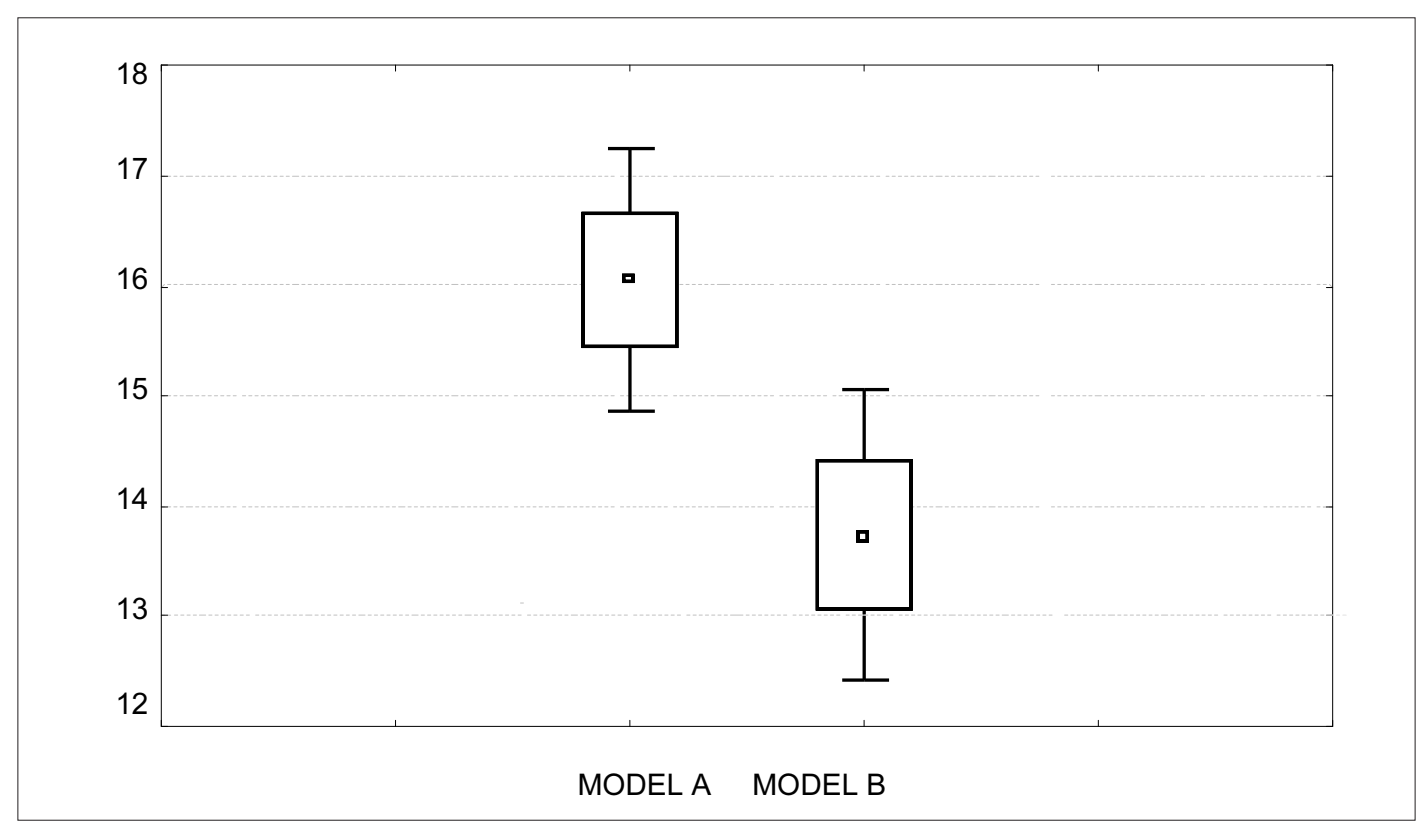

Figure 2. Average values achieved in the chair stand trial in pulmonary rehabilitation models $A$ and $B$ 
value achieved by patients in rehabilitation model $A$ was $16.4 \pm 2.45$, and in model B it was $17.7 \pm 2.64$ (Figure 2).

Statistically significant differences were observed in the chair sit and reach trial. Average value achieved by patients in rehabilitation model A was $0.52 \pm 2.9$, and in model $B$ it was $6.26 \pm 7.1$ (Figure 3).

Statistically significant differences were also observed between average values achieved by patients from rehabilitation models $A$ and $B$ when the 10-point scale was used for each trial (Table 4).

Statistically significant differences were observed with the use of the 10-point scale. For patients from rehabilitation model A the average result was $42.8 \pm 7.46$ and for model B $-25.28 \pm 10.56$ (Figure 4).
Table 4. Average values achieved on the 10-point scale in six trials of the Fullerton test for rehabilitation models $A$ and $B$

\begin{tabular}{|c|c|}
\hline Model A & $42.8 \pm 7.46$ \\
\hline Model B & $25.28 \pm 10.56$ \\
\hline
\end{tabular}

Patients qualified for rehabilitation model A scored between 27 and 55 points. Patients qualified for rehabilitation model B scored between 9 and 33 points. Higher index values were recorded for patients in rehabilitation model A characterised by higher effort tolerance, lower dyspnea level, better physical condition and smaller degree of ventilation activity disorder in comparison with patients qualified for model $\mathrm{B}$.

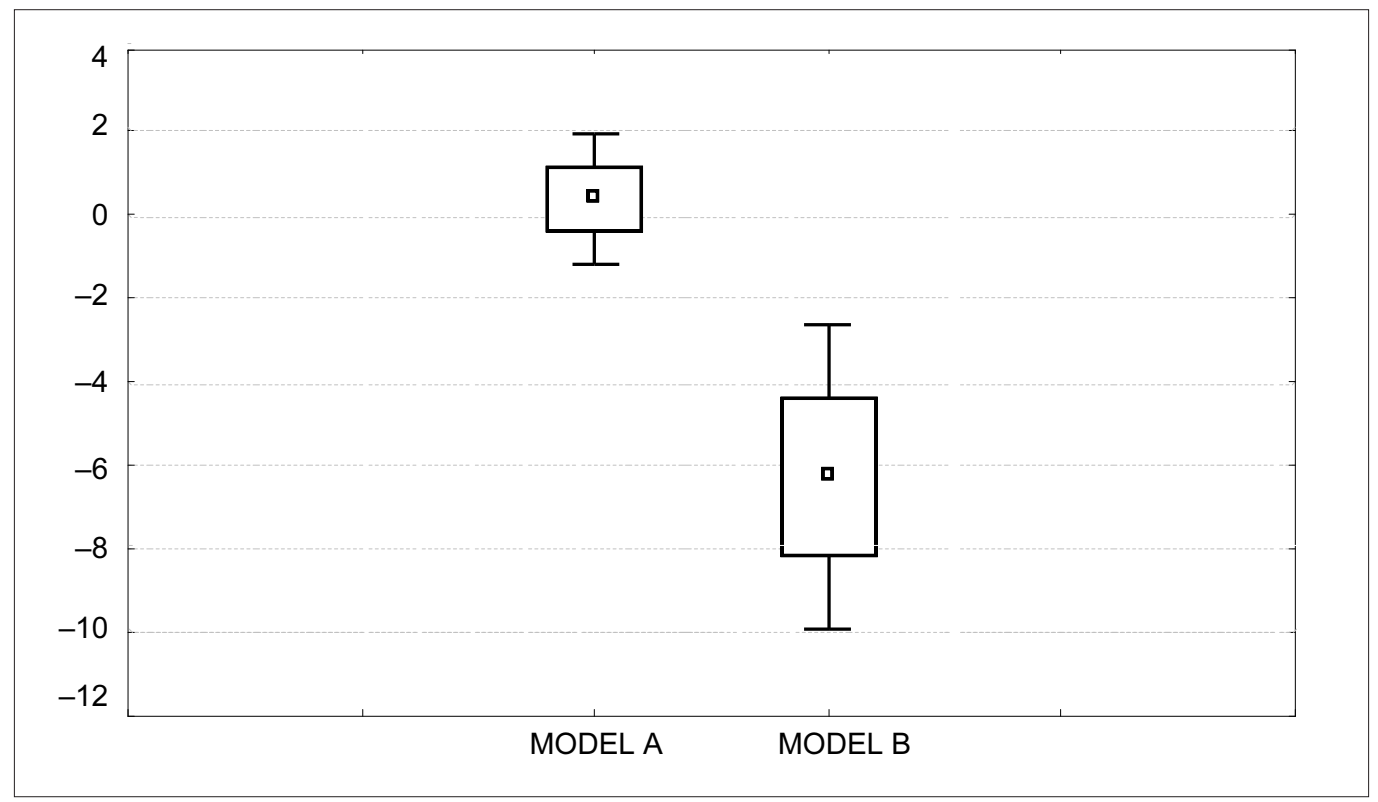

Figure 3. Average values achieved in the sit and reach trial for rehabilitation models A and B

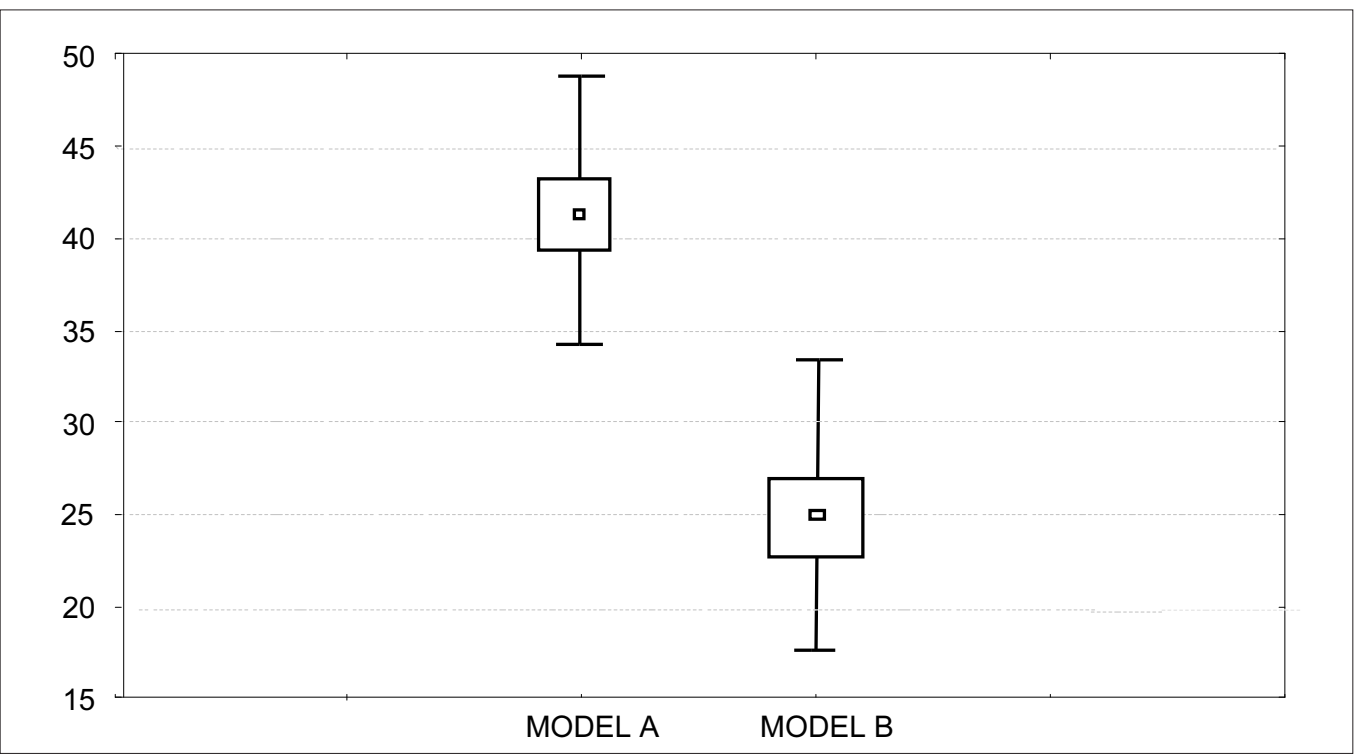

Figure 4. Average values recorded on the 10-point scale in six trials of the Fullerton test for rehabilitation models $A$ and $B$ 


\title{
DISCUSSION
}

The Functional Fitness Test was created to assess functional fitness in elderly patients and is widely used for this purpose $[5,6,7]$. The norms of values for each component of the test were drawn up by the authors, R. Rikli and J. Jones, based on the sample of 7183 healthy volunteers from California aged 60-94 [5, 6]. In Poland, the first attempt to assess the usefulness of the Fullerton test as a measure of elderly people's fitness was made by A. Rozanska-Kirschke [7]. P. Raglewska et al. [9] also used the six simple trials of the Fullerton test to assess the influence of rehabilitation on physical condition of the elderly and patients with respiratory system diseases $[8,9]$. The results showed the test's usefulness in the assessment of rehabilitation progress. Professional literature does not provide complex study on the usefulness of using the Fullerton test in the process of qualifying patients for pulmonary rehabilitation. Based on own research we suggest that the Fullerton test might be useful for qualifying patients with COPD for pulmonary rehabilitation. However, it seems that it cannot replace standard qualification which includes lung functional activity and dyspnea assessment which constitute a significant element of functional assessment in pulmonary rehabilitation. The possibility of using the Fullerton test for qualification purposes requires further research.

\section{CONCLUSIONS}

1. Patients who scored higher on the scale invented by the authors were qualified for higher pulmonary rehabilitation models, which means they achieved higher results in qualification tests.
2. The Fullerton test might be useful for the assessment of the results and progress of pulmonary rehabilitation.

\section{REFERENCES}

1. Szczegielniak, .J, Bogacz, K., Luniewski, J. (2010). Kwalifikacja do rehabilitacji chorych na POChP. Practical Physiotherapy and Rehabilitation, 12, 9-11.

2. Szczegielniak, J., Bogacz, K., Luniewski, J. (2010). Program rehabilitacji chorych na POChP cz I. Practical Physiotherapy and Rehabilitation, 12, 12-19.

3. Kozak-Szkopek, E. (2007). Ocena kliniczna chorego w podeszłym wieku z przewlekłą obturacyjną chorobę płuc. Gerontologia Polska, 15 (3), 61-68.

4. Luniewski, J., Szczegielniak, J., Krajczy, M., Bogacz, K. (2011). A new way of interpreting the results of the six-minute walk test with the use of the Genetic Algorithm. Poster session presented at: 16th International WCPT Congress, Jun 20-23, Amsterdam, Holland.
5. Rikli, E., Jones, J. (1999). Development and validation of funcional fitness test for community residing older adults. The Journal on Active Aging and Physical Activity, 7, 129-161.

6. Rikli, E., Jones, J. (2002). Measuring functional. The Journal on Active Aging and Physical Activity, 24-30.

7. Rozanska-Kirschke, A., Kocur P., Wilk, M., Dylewicz, P. (2006).The Fullerton Fitness Test as an index of fitness in the elderly. Medical Rehabilitation, 10 (2), 9-16.

8. Kaliszewska-Szczepaniak, A., Barinow-Wojewodzki, A., Raglewska, P. (2005). Test Fullertona jako ocena sprawności fizycznej u pacjentów z chorobami układu oddechowego. Poznań.

9. Raglewska, P., Cywińska-Wasilewska, G., Barinow-Wojewodzki, A. (2005). Rola rehabilitacji pulmonologicznej u chorych na przewlekłą obturacyjną chorobę płuc. Physiotherapy, 13, 28-32.

\section{FULLERTON TESTO NAUDINGUMAS SKIRIANT REABILITACIJA LIGONIAMS, SERGANTIEMS LĖTINE OBSTRUKCINE PLAUČIŲ LIGA}

\author{
Jan Szczegielniak1,, Anna Wdowiak', Katarzyna Bogacz', 2, Jacek Luniewski ${ }^{1}$ \\ Opolés technologijos universitetas ${ }^{1}$ \\ Glucholazu MSWiA ligoniné2
}

\section{SANTRAUKA}

Asmeniškai parinkti pratybų rūšis ir intensyvumą yra labai svarbu taikant fizioterapiją (kineziterapiją) sergantiesiems LOPL (lètine obstrukcine plaučių liga). Pagrindinis pratimų skyrimo kriterijus yra ligonių pastangų tolerancija, kuri įvertinama veloergometrija arba šešių minučių èjimo testu, taip pat matuojant plaučių ventiliacijos sutrikimo laipsnį, dusulio stiprumą ir bendrą ligonio fizinę būklę. Fullerton testas yra lengvas ir laiką taupantis metodas, leidžiantis ištirti vyresnių nei 60 metų ligonių pastangų toleranciją ir bendrą fizinę būklę. Tyrimo tikslas - ištirti Fullerton testo naudingumą skiriant reabilitaciją sergantiesiems LOPL.

Buvo tiriami 32 ligoniai, kuriems diagnozuota LOPL. Visi jie buvo stacionarūs ligoniai, gydomi Glucholazų MSWiA ligononėje nuo 2011 metu vasario 1 d. iki gegužès 10 d. Visi tirti ligoniai buvo vyresni nei 60 metų (amžiaus vidurkis $-68 \pm 5,2$ m.). Visiems buvo paskirta A ir B modelio reabilitacija pagal J. Szczegielniak metodiką. Šio tyrimo metu šešių Fullerton testo taikymo atvejų rezultatai buvo lyginami su standartinių testų, naudojamų plaučių ligų reabilitacijos metu, rezultatais. Buvo sukurta 10 balų skalè, kuri leistų palyginti Fullerton ir standartinio testo rezultatus. Taikant Stjudento $t$ testą, buvo įvertinti ryšiai tarp tiriamų rodiklių. Pasirinktas statistinio reikšmingumo lygmuo $-\mathrm{p}<0,05$.

Tyrimo rezultatų analizè parodè, kad tiems ligoniams, kurie surinko daugiau skalès balų, buvo skiriamas stipresnės reabilitacijos modelis, taigi jie surinko ir daugiau reabilitacijos testų taškų.

Fullerton testas gali būti naudingas vertinant sergančiųjų plaučių ligomis reabilitacijos rezultatus ir stebint reabilitacijos eigą.

Raktažodiai: Fullerton testas, pastangų tolerancijos vertinimas, plaučių ligų reabilitacija. 